\begin{tabular}{|ll|l|}
\hline Submited $:$ 2021-02-17 & Accepted $:$ 2021-06-29 \\
\hline Revised $:$ 2021-03-20 & Published $:$ 2021-07-03 \\
\hline
\end{tabular}

\title{
The Implementation of Literary Works for Promoting Student Involvement in Learning English Grammar
}

\author{
Asfi Aniuranti ${ }^{1}$, Dinar Faiza ${ }^{2}$, Yasinta Wulandari ${ }^{3}$ \\ ${ }^{123}$ Universitas Nahdlatul Ulama Purwokerto \\ 1a.aniuranti@unupurwokerto.ac.id, 2d.faiza@unupurwokerto.ac.id, \\ 33.wulandari@unupurwokerto.ac.id
}

\begin{abstract}
Nowadays, every teaching and learning process is supposed to apply a studentcentered concept in which the pupils are the center of the process, and they are encouraged to participate actively in the process. Therefore, all education levels have implemented this concept, including the university level. Unfortunately, many pupils are still passive during the teaching process. This phenomenon also appears in the English Language Teaching Department of Universitas Nahdlatul Ulama Purwokerto. The low participation of the students happens in all classes, including grammar class. Based on the pre-observation process in a grammar class, the average score of student participation was only $58.82 \%$. From seven categories of student participation, two indicators were still $0 \%$ called asking a question and giving constructive or positive comments to the teacher or other students. There was also one category that only achieved $41.18 \%$. Besides, the atmosphere was not conducive since some students talked to their classmates and looked quite bored. Based on this condition, the researchers decided to do action research. After doing a literature study, we agreed to use literary works to overcome the problem. The research was done in one cycle that consisted of three meetings. The instruments used for collecting the data were an observation sheet of student participation and a teacher observation sheet. The data gathered
\end{abstract}


were analyzed using simple statistics like percentage and average score, then the analysis presented through diagram and words. The literary works used in this study were a short story, a film script, and a novel. This action research is successful if the percentage of student involvement can achieve $65 \%$. The result reveals that student participation was getting better after the implementation of literary works in the teaching and learning process. In the first action, the average percentage was $69.29 \%$, then it became $75.89 \%$ in the second meeting. In the third act, the student involvement achieved $78.15 \%$. The most impressive finding appeared in the third meeting. Three students asked questions. Asking questions as one of the indicators of participation did not appear in the first and the second meeting. The atmosphere was getting conducive since the implementation of the literary works in the grammar class. In short, this action research is successful in boosting student involvement in grammar class.

Keywords: student involvement; grammar; literary works; action research

\section{A. Introduction}

In every teaching and learning process includes EFL class, the students are the core of the process. This concept is also well known as student-centered learning. Nowadays, there is a shift from teacher-centered to student-centered learning (Mokoginta, 2013; Suwartono \& Aniuranti, 2018). Emaliana (2017) argues that student-centered learning gives the students the chance to boost their analytical abilities, problem-solving skills, skills in deep learning, lifelong learning, self-directed learning, reflective learning, and motivation. Thus, the shift is not without reason.

In applying the student-centered concept, student participation is considered an indispensable part of the teaching and learning process. Suwartono \& Aniuranti (2018) argue that every teacher has to achieve teaching objectives by involving the students in the learning process. Aneteneh (2014) adds that without student participation, the instructional objectives are impossible to accomplish. Student involvement is paramount in English language teaching (Suwartono \& Rahadiyanti, 2014; Abebe \& Deneke, 2015). Overall, student involvement is an essential part of achieving the teaching goals. 
The importance of student involvement is undeniable, but fostering the students to join the class is not a simple thing for the teachers. The students are frequently reluctant to participate in the teaching process, and this happens almost in all levels of education includes higher education.

The researchers find out that student participation is still low, and this mostly appears in grammar classes. It might occur since grammar is commonly considered a hard language component. According to Yunita, Mayuni \& Emzir (2018), in Indonesia, learning English grammar is still regarded as a challenging matter for the students in the EFL context. Besides, based on the pre-observation conducted in the Intermediate Grammar class, the average percentage of student participation was $58.82 \%$. Furthermore, two indicators of student participation were still $0 \%$ called asking a question and giving constructive or positive comments to the teacher or other students. Furthermore, the learning atmosphere was not conducive because some students talked to their classmates and looked quite bored.

Based on the situation, to promote student involvement in grammar class, the researchers decided to do action research. One way that is worth trying as an alternative solution is literary works. Literary works are considered as effective media due to their advantages. According to Floris (2004), there are at least four benefits of using literary works as teaching media. They are language enrichment, culture enrichment, authentic material, and personal involvement. Khatib, Rezaei, \& Derakhshan (2011) even explain nine benefits of literary works such as authenticity, motivation, cultural/intercultural awareness and globalization, intensive/ extensive reading practice, sociolinguistic/pragmatic knowledge, grammar and vocabulary knowledge, language skills, emotional intelligence (EQ), and critical thinking.

In this study, the classroom research model employed was Kemmis and McTaggart model in Kusumah and Dwitagama (2010). This model consists of four phases. They are planning, observing, acting, and reflecting. The observing and acting stage is one activity. In this study, the action 
research conducted consisted of one cycle. The data were collected through observation and analyzed through simple statistics like percentage and average score.

\section{B. Finding}

Based on the result of pre-observation, the average percentage of student participation was only $58.82 \%$. Furthermore, the teaching atmosphere did not seem conducive since the lecturer used a conventional way of teaching. Some students looked bored and talked to their friends during the class. Pay attention to the following picture.

\section{Picture 1}

Some students are talking to their friends

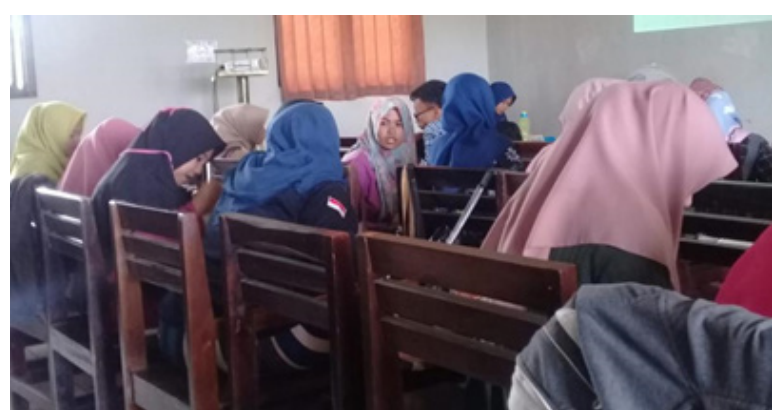

After using some literary works such as a short story, a novel, and a film script as teaching media, the results of student participation became better than the pre-observation. In meeting 1, the average percentage was $69.29 \%$, then it became $75.89 \%$ in meeting 2 , and achieved $78.15 \%$ in meeting 3 . The most interesting finding appeared at the end of the cycle. Three were students asking questions. This indicator did not even appear in the first and second meetings. Pay attention to the following picture. 
The Implementation of Literary Works for Promoting Student ...

Picture 2

A student is asking question

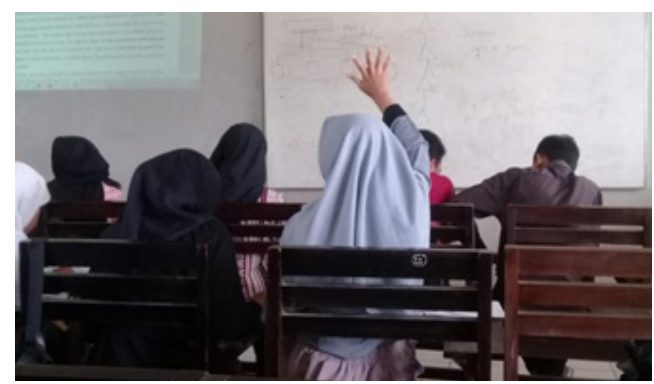

Overall, the development of student participation can be seen in the following diagram:

Diagram 1

Average of Student Participation

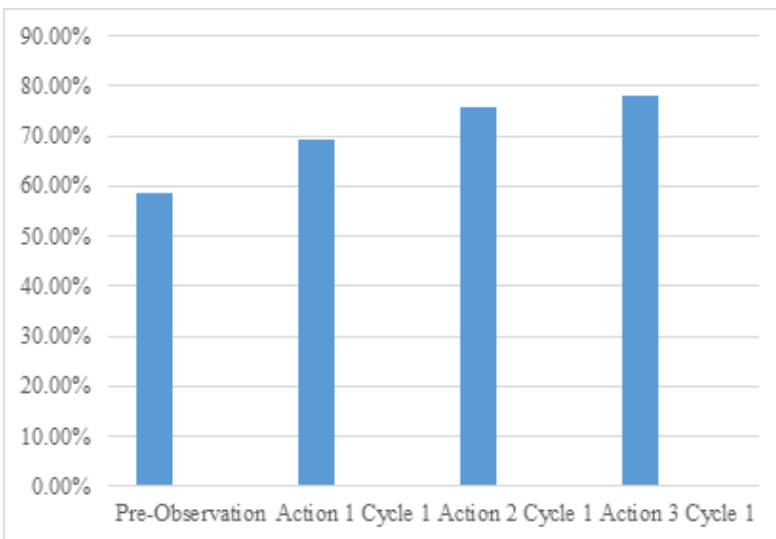

Based on the diagram above, the average percentage of student participation achieved $78.15 \%$ at the end of the cycle. This percentage surpassed the successful criterion (65\%). Moreover, the class atmosphere seemed better when the teacher used literary works. The students looked more enthusiastic and focused on joining the class. 


\section{Discussions}

In this study, the final result of student involvement (78.15\%) was higher than the successful criterion (65\%). This is assumed due to the power of literary works. Khatib, Rezaei, \& Derakhshan (2011) point out one of the benefits of using literary works is a motivation tool. They say that experience shows that students are highly motivated when they are exposed to literary texts for language learning purposes. Motivating the students through literary work might influence their willingness to involve actively in the teaching and learning process. In addition, literary works might also be used to encourage the students to think critically. That is likely the reason for the appearance of asking a question as one of the indicators. In short, literary works as teaching media can be utilized to promote student participation in learning English grammar.

\section{Conclusions}

The result reveals that student participation became better after the implementation of literary works as teaching media. In meeting 1 , the average percentage was $69.29 \%$, then it became $75.89 \%$ in meeting 2 . In meeting 3 , the percentage achieved $78.15 \%$. The final percentage was higher than the successful indicator (65\%). The most impressive finding appeared at the end of the cycle. There were three students who asked questions. This indicator did not appear in the first and second meetings. Overall, this study is successful in boosting student participation. Moreover, the teaching atmosphere seemed more conducive. 
The Implementation of Literary Works for Promoting Student ...

\section{References}

Abebe, Dawit Tesfaye.,\& Deneke, Tsadik. 2015. Causes of Students' Limited Participation in EFL Classroom: Ethiopian Public Universities in Focus. International Journal of Educational Research and Technology, Volume 6, Issue 1: 74-89.

Aneteneh, Atalay Mesfin. 2014. Student's Classroom Participation in English Language Teaching: The Case of Gozamen General Secondary School in Grade 10A. Socrates, Volume 2, Issue 2: 204217.

Emaliana, Ive. 2017. Teacher-centered or Student-centered Learning Approach to Promote Learning?. Jurnal Sosial Humaniora, Volume 10, Issue 2: 59-70.

Floris, Flora Debora. 2004. The Power of Literature in EFL Classrooms. K@TA, Volume 6, Issue 1: 1-12.

Khatib, Mohammad., Rezaei, Saeed., \& Derakhshan, Ali. 2001. Literature in EFL/ESL Classroom. English Language Teaching, Volume 4, Issue 1:201-208.

Kusumah, Wijaya., \& Dwitagama, Dedi. 2010. Mengenal Penelitian Tindakan Kelas. Jakarta: PT Indeks.

Mokoginta, Karmila. 2013. Student-Centered Learning (SCL) Approach In EFL Classes. Bahasa dan Seni, Volume 41, Issue 2:239-247.

Suwartono, Tono.,\& Aniuranti, Asfi. 2018. Digital Teaching Tools in 21st Century EFL Classroom: Are Our Teachers Ready? Journal of English Language, Literature, and Teaching (ELLITE), Volume 3, Issue 2: 57-62.

Suwartono., \& Rahadiyanti, Dewi Puji. 2014. The Use of Songs for Promoting Student Participation in the Teaching of English Structure. Proceeding of the 61 st TEFLIN International Conference. UNS Solo. 
Asfi Aniuranti, Dinar Faiza, Yasinta Wulandari

Yunita, Wisma., Mayuni, Ilza.,\& Emzir. 2018. Integrated Story-Based Grammar Learning Model: The Effectiveness and Students'Perception on Its Implementation in a Grammar Classroom. Advances in Social Science, Education and Humanities Research, Volume 178: 296-303. 